\title{
Augusto Graziani: Theoretician, Applied Economist, Historian of Economic Thought-An Appraisal
}

\author{
Lilia Costabile
}

Received: 20 November 2014 / Accepted: 23 January 2015 / Published online: 14 February 2015

(C) Società Italiana degli Economisti (Italian Economic Association) 2015

\begin{abstract}
Augusto Graziani, one of the leading Italian economists in his generation, brought to economics the gifts of an analytically-oriented mind, crystal-clear logical reasoning, flawless erudition, and a passionate interest in the political and policy implications of both theoretical models and empirical analysis. After a presentation of Graziani's life and career, this article investigates the links connecting his theoretical evolution from general equilibrium analysis to circuit theory, his interpretation of the development of the Italian economy, and his approach to the history of economics. While recognising change in his analytical framework, I argue in favour of a basic continuity in his thought around the central themes of capital accumulation and the origins of its ownership and control.
\end{abstract}

Keywords Augusto Graziani - General equilibrium theory · Circuit theory · Italian economy $\cdot$ History of economics

JEL Classification $\quad \mathrm{B} 31 \cdot \mathrm{B} 59 \cdot \mathrm{D} 51 \cdot \mathrm{E} 40 \cdot \mathrm{E} 51$

\section{Introduction}

Augusto Graziani (Naples, 4 May 1933-Naples, 5 January 2014) was one of the leading Italian economists of his generation. He brought to economics the gifts of an

I wish to thank an anonymous referee of this journal for her/his useful comments on a previous version of this article. I also thank Angela Graziani, who kindly read this article. The usual disclaimer applies.

\section{Costabile $(\varangle)$}

Dipartimento di Scienze Economiche e Statistiche, Università di Napoli Federico II, Naples, Italy e-mail: costabil@unina.it

L. Costabile

Clare Hall, Cambridge, UK 
analytically-oriented mind, crystal-clear logical reasoning, flawless erudition, and a passionate interest in the political and policy implications of both theoretical models and empirical analysis.

He contributed to economic theory, applied economics, and the history of economic thought. After a presentation of Graziani's life and career (Sect. 2), in this article I illustrate the coherence among his writings in these three fields by investigating the links connecting his theoretical evolution (Sect. 3), his interpretation of the development of the Italian economy (Sect. 4), and his approach to the history of economics (Sect. 5).

Central to Graziani's investigations in the three above fields was his interest in capital accumulation within the dynamic evolution of economic systems: this interest inspired his interpretation of general equilibrium theory and the controversies surrounding this approach in the 1960s, as well as, later on, his inquiries into the nature of capital and the origins of its ownership and control. This line of inquiry led him away from general equilibrium analysis, although, as we shall see, he always maintained an attitude of great respect for this theoretical approach. His theory of the monetary circuit — the arrival point of his intellectual trajectory-models the market economy as a sequential, hierarchical system in which only selected agents are able to influence strategic variables, such as the rate of capital accumulation, the levels and sectoral compositions of both output and employment, and the distribution of income.

Graziani's theoretical evolution is also reflected in, and inspired by, the simultaneous evolution of his empirical work. While his reading of post-war economic growth in open economies during the 'miracle' years emphasised dynamic factors such as technical change and productivity growth in response to the international integration of markets, his vision gradually became more focused on the conflicting strategies of macro-groups and their consequences on aggregate outcomes, with particular reference to the evolution of the Italian economy and its integration into Europe.

Finally, both in Graziani's theoretical writings and in his studies on the history of economic thought, references to the work of other economists also evolved from his initial concentration on general equilibrium theorists to interest in a more complex group including the founders of the theory of a 'monetary economy of production', the theoretical approach that he came to regard as most congenial to his own viewpoint, and to the development of which he creatively contributed.

Besides illustrating the coherence among the various lines of Graziani's inquiry, I shall also try to answer the question of whether his intellectual trajectory is characterised by continuity or discontinuity. While recognising change in his analytical framework, I argue in favour of a basic continuity in his thought.

In the remaining part of this Introduction, before illustrating Graziani's life, career and intellectual profile in the following sections, let me just very briefly mention some personal memories. Augusto-his ironic smile hovering at the corner of his mouthonce told me that commemorations provide their authors with a splendid opportunity to talk about themselves on the pretext of describing aspects of the commemorated person's intellectual and personal relationships. He was critical, and at the same time 
tolerant, of human vanity. With that ironic smile in my mind, I shall keep references to my intellectual collaboration with him to the minimum. ${ }^{1}$

Graziani's intellectual prestige was evident. I remember young and old economists alike, who had been lingering to chat in the corridors at a Conference held in 1978, hastening back to the conference hall when they heard that Graziani was about to speak. And he rarely disappointed his audience: whether or not the listeners accepted his propositions, which often challenged the 'conventional wisdom', his full control of the analytical aspects of the issues involved, his logical arguments, and his limpid style made his speeches a memorable experience, and provided the audience with invaluable food for thought.

One of the greatest lessons he gave to his pupils and colleagues was disinterestedness: by which I certainly do not mean that he was a neutral or disengaged actor or observer. Rather, I mean that he never let his personal interests restrain the freedom of his thought. In other words, he was an intellectual in the noblest meaning of the word: the kind of figure that we most need today.

\section{His Life and Career}

Graziani was born in Naples on the 4th of May 1933, into a family of academics ${ }^{2}$. His father, Alessandro, was a highly regarded professor of commercial law (diritto commerciale); his grandfather, Augusto Graziani sr., had been a well-known professor of economics, who in 1899 moved from Modena to Naples with his wife Paolina Friedmann. Their initial intention had been to stay there for only a few months, but in fact Augusto sr., Paolina and their descendants never relocated from Naples, which Augusto jr. once described as the most beautiful city in the world.

Adelina Fano, professor Alessandro's wife, and mother of Augusto jr., was an amateur piano player accustomed to organising a music ensemble in her house. Thus, the younger Augusto inherited from his grandfather and his mother respectively the two main intellectual interests of his life: economics and music. He started to play the violin at the age of fourteen, and he later passed his examinations for the fifth year of the music conservatory. He continued to play for the rest of his life. Only to few lucky friends did he grant the honour and pleasure of attending some of his ensemble music sessions. Augusto Graziani's wife, Angela Celentano and their two daughters, Rebecca and Sandra, together with a generation of grandchildren inaugurated by another little Augusto, contributed to giving him what he described as a "wonderful, serene life" (Graziani 2006).

During fascism, the Graziani family, being Jewish, suffered discrimination: Alessandro, then 38 years old, had to leave university. Giuseppe Cenzato, president of the private Southern Electrical Company (SME), gave him work in the company's

\footnotetext{
1 Although I cannot resist recalling my pleasure when he once described my mind as "Cartesian".

2 My sources on Graziani's life and views are his interviews published in Meridiana (Graziani 1993) and La Repubblica (Graziani 2006), as well as my own conversations with him, including the interview referred to in Costabile (2004). I am also grateful to Angela Graziani for our conversations on Augusto's family and his life and career. In the present article, I build on Costabile (2004, 2014). The translations into English of his works in Italian are mine.
} 
legal office. In that period, Augusto was educated at home by a private tutor. After the fall of fascism, he attended the then celebrated Umberto Lyceum in Naples. He was an outstanding student. Upon finishing high school, he enrolled at the Faculty of Law of the University of Naples Federico II, and in 1955 he graduated with a dissertation in economics under the supervision of Giuseppe Di Nardi.

Between 1956 and 1959 Graziani completed his education abroad. At the London School of Economics he attended the courses of Lionel Robbins (economic philosophy), James Meade (international trade), Roy G.D. Allen (mathematics for economists), Arnold Plant (industrial economics and firms' strategies). In 1958-1959 he was at Harvard University, were he attended courses given by Wassily Leontieff (inputoutput analysis), James S. Duesenberry (macroeconomics) and John K. Galbraith (economic development). However, his closest intellectual relationship was with Paul Rosenstein-Rodan, then at the Massachusetts Institute of Technology, who encouraged him to write an unpublished paper on regional inequalities. Rosenstein-Rodan, then a leading figure in development economics and in the World Bank's policies for economic development, also established a contact between Graziani and Manlio Rossi-Doria, the great Italian intellectual and agricultural economist who was about to found, in 1959, the "Centre for Specialization and Research in Economic and Agricultural Sciences for the Mezzogiorno" or, briefly, the Portici Centre. Together with the SVIMEZ (the Association for the Development of Southern Italy, of which Graziani also became a member), the Portici Centre was the Italian think-tank on development theory and policy from its foundation. It also provided the only opportunity for postgraduate studies, at a time when Ph.D. programmes were still non-existent in Italy. In 1959 Graziani joined the staff of the Portici Centre, where he taught and conducted research until the mid-1980s.

Graziani became full professor when he was just 27 years old. His first chair was at the University of Catania, whence he moved to Naples (from 1963 to 1989) and finally to Rome. He also lectured at many universities and other institutions outside Italy (Birmingham, Michigan, Dijon, Paris III, College de France).

In the course of his long career, Graziani received many honours. In addition to being a member of the most prestigious academies, such as the Accademia dei Lincei, the Turin Academy of Sciences, and the Neapolitan Accademia Pontaniana, he was the President of the Italian Economists' Society between 1998 and 2001, and a member of the boards of directors of the Antonio Gramsci Foundation and of SVIMEZ.

He was also a consulting editor of the Journal of Economic Literature, the general editor of Studi Economici, and a member of the scientific/honorary boards of several other journals (including Economie Appliquée, Il Pensiero Economico Italiano, the European Journal of the History of Economic Thought). He was a honorary member of the Associazione Italiana per la Storia del Pensiero Economico. He contributed with comments on current economic affairs to some of the main Italian newspapers.

Finally, he was a member of the Senate during the ninth legislature of the Italian Republic, and a member of the boards of the Bank of Naples and of the Istituto Banco di Napoli-Fondazione. 


\section{Theory: From General Equilibrium to Circuit Analysis}

Graziani's theoretical writings can be divided into two groups: those dealing with general equilibrium theory, and those pertaining to the circuit approach to economic analysis. He pursued the first line of analysis in Equilibrio generale ed equilibrio macroeconomico [General Equilibrium and Macroeconomic Equilibrium] (1965) (Graziani 1965) and some related writings (e.g. Graziani 1964, 1966a). His contributions to the second line were many. Among them, to be mentioned in particular are his Introduction to Costabile (1980), one of his first presentations of his new approach; Moneta senza crisi [Money without Crises] (Graziani 1984a); The Theory of the Monetary Circuit (1989b); La teoria monetaria della produzione [The Monetary Theory of Production] (1994); The Monetary Theory of Production (2003), an expanded version of the former book.

Equilibrio generale ed equilibrio macroeconomico, his first theoretical book, was published in 1965, when the Sraffian critique of general equilibrium analysis was gaining consensus among economists, especially in Italy and in Cambridge, UK. Graziani, too, was critical of general equilibrium analysis, but for different reasons. In his critique, he focused on the problem of fixed capital, just as the Anglo-Italian school was doing in that period. But, differently from that line of thought, he defended the Walrasian model as a logically consistent representation of single-period equilibrium. ${ }^{3}$ What he objected to was its relevance for economic dynamics and for the "central issue of modern economic theory", namely "the distribution of income between consumption and investment, and hence the economy's rate of growth" (Graziani 1965: 9).

His critique of general equilibrium theory went as follows. Because fixed capital goods are durable goods, they establish a link between time periods. Whilst in singleperiod models competition equalises profit rates on all capital goods, in economies moving through time the competitive process generates positive and negative rents. This happens because the competitive process equalises the prices of capital goods produced in different time periods (e.g. at time $\mathrm{T}$ and at time $\mathrm{T}-1$ ), thus making the buyer indifferent between new and old capital goods. From this it follows that positive or negative rents arise according to whether the seller of an old capital good at time $\mathrm{T}$ gets a price higher or lower than its historical cost. In other words, competition cannot perform two tasks at the same time, i.e. equalising prices and rates of return between capital goods of different vintages (Graziani 1964: 635-638; Graziani 1965, chap. 3). Thus, Graziani's allegation against general equilibrium theory-in the Walras-Pareto formulations-is not that of "internal inconsistency" but of a "lack of substance" (Graziani 1964: 639), because "while capital goods live for a long period, equilibrium as defined by the model is merely an instantaneous equilibrium valid in the moment when capital goods are produced" (Graziani 1964: 637).

This analysis opens the way to a dynamic conception of competition and efficiency with a strong Schumpeterian flavour. In this approach, "dynamic processes are not equilibrium processes" (Graziani 1965: 96), because the intertemporal equalization of

\footnotetext{
3 See the debate between Graziani (1964, 1966a) and Garegnani (1966).
} 
profit rates is "incompatible with economic development understood as the evolution of production structures" and as "structural change" (Graziani 1965:11; 98). In dynamic economies, resources move from declining sectors, where rates of return are lower, to expanding sectors, where returns are higher, thus enhancing economic efficiency. This reallocation of the economic process is the very essence of economic dynamics, and all incentives to dynamic efficiency would come to a standstill under 'full' intertemporal equilibrium, i.e. if profits rates were uniform through time (Graziani 1965: 98).

On these premises, Graziani held firmly to his definition of "a dynamic situation" as:

"one in which the economic system is characterised by on-going capital accumulation (that is, not a single act of capital accumulation) and by regular technical progress (that is, not an individual innovation or improvement occurring just once)" (Graziani 1966a: 3).

Because current theoretical models - of both the general equilibrium and the 'balanced-growth' variety-were unsuited to the purpose of dynamic analysis and structural change (Graziani 1964, 1993: 214) ${ }^{4}$, Graziani had to build his own analytical tools. This task he undertook in The Development of an Open Economy (Graziani 1969), a collection of essays written by a research group based in Portici and directed by him. In the first four chapters (the fourth written in collaboration with Bruno Trezza) Graziani developed the theoretical model of an open economy where the driver of growth and structural change is final demand: more precisely, export demand. In his export-led growth model, the dynamic sector specialises in the products for which world demand is expanding, irrespective of resource endowments and comparative advantage, because this is a strategy more convenient than specializing in traditional, stagnating sectors. Moreover, once the choice of entering the world market has been taken, international competition also dictates the rate of productivity growth, investment, and the appropriate technologies in the exporting sector. The causal order of traditional static theory is thus reversed: growth, international specialization and productivity are not determined by factor endowments, costs or other supply-side factors, but by exports and the evolution of international demand. ${ }^{5}$ Thus, Graziani's interest in economic dynamics led him away from general equilibrium theory not just in its general form but also in its international trade version.

To be noted is that, at this stage in his intellectual development, Graziani was already fully aware of the theoretical implications of his approach. As he wrote in a recently rediscovered set of lectures that he delivered at SVIMEZ in 1966, Il contenuto della politica economica, in a dynamic situation "the theoretical frameworks of traditional economics [...] break up" (Graziani 1966b: 4). He pointedly enumerated the failures of traditional economics in a dynamic context: (a) the axiom that consumers know their preferences fails because they do not know about potential new products, since the directions taken by $R \& D$ and the implementation of new production lines

\footnotetext{
4 Graziani extended this judgement to von Neumann's model, which he likened to aggregative models because of its hypothesis that relative prices and quantities are constant over time. This hypothesis, he argued, amounts to assuming a single aggregate commodity (Graziani 1965: 90).

5 We will see below how Graziani applied this model to Italian economic development in the post-war period.
} 
are the province of entrepreneurs' decisions ${ }^{6}$; (b) in a dynamic economy, firms face an expanding market, i.e. neither a horizontal demand curve as in perfect competition models, nor a downward sloping demand curve as in imperfectly competitive markets; (c) firms do not maximise profits, but rather their growth as a strategy to survive by expanding their market shares; (d) for all the above reasons, the 'optimum' position of the economy is undefined. Thus, these lectures given in 1966 are important documentation because they show that, in his subsequent theoretical evolution, Graziani was bringing to full maturity the seeds already sown in his early work on general equilibrium analysis.

Yet, in spite of the distance that Graziani put between himself and the orthodox approach, he always maintained an attitude of great respect and admiration for the theory of general equilibrium, which, as he put it in a long interview published in 1993, he regarded "as one of the most perfect theoretical castles" (Graziani 1993: 203). Looking at general equilibrium theory 'from outside', he was still impressed with its being "the best constructed house" (not a surprising circumstance, he added, given the amount of intellectual and material resources devoted to it); and with its resilience even to sound criticisms, such as those brought against it by the Sraffians (ibid.: 215).

In the course of these reflections, Graziani also clarified his methodological stance concerning competing theoretical frameworks. With typical irony he declared himself uninterested in looking for damage in someone else's house: he preferred to leave the task of repairing it to the house's owners (ibid.: 214). This explains his scant interest in 'internal' theoretical criticisms, i.e. "those criticisms that go searching for the mistake in the logical structure of a theory": his alternative research strategy consisted in building his own theoretical house.

This attitude reflects a deeper methodological belief: that logical consistency is a necessary condition for a model to be viable, but not a sufficient condition for good economic theorizing. Economic models must also be relevant and fertile, i.e. able to provide convincing explanations for the problems or facts under investigation.

Graziani's 'considered ambivalence' towards general equilibrium theory closely resembled the approach taken by Joseph Alois Schumpeter. In the realm of pure statics, Schumpeter argued, general equilibrium theory was the "Magna Carta" of economic analysis (Schumpeter 1977: 66). Yet, at the same time, he considered that framework to be a "straitjacket" (ibid.:155) for the analysis of capital formation, the theory of saving, and the problem of economic progress" (ibid.). ${ }^{7}$ Graziani's approach is very similar, and the reader cannot fail to notice the identification between the author and his subject in some parts of Graziani's description of the 'orthodox' and the 'unorthodox' Schumpeters in his fine Introduction to the abridged Italian version of the Austrian economist's Business Cycles (Graziani 1977).

\footnotetext{
6 Graziani's point is very similar to that made by Schumpeter in his book Business Cycles, when he noted that the introduction of railways, electricity and other new products occurred on the initiative of entrepreneurs, and certainly not in response to changes in consumers' tastes and demand. Changes in demand, Schumpeter argued, had been "imposed" on consumers. Later in his career, Graziani did not fail to quote, approvingly, this passage in his Introduction to the Italian edition of Schumpeter's book (Graziani 1977: 21). In this context, he also noticed Schumpeter's "iconoclastic" attitude towards the axiom of consumer's sovereignty, one of the central tenets of the traditional approach.

7 For an interpretation of Schumpeter's approach along these lines see Costabile (1986).
} 
Graziani's focus on the dynamic phenomenon of capital formation opened the way to a full reconsideration of the foundations of a market economy. And, again as in Schumpeter's case, the outcome of this theoretical enterprise was something more radical than a mere extension of general equilibrium theory to the intertemporal dimension, ${ }^{8}$ because the issue of capital accumulation raised the further, basic question of how to define the nature of capital and the origins of its ownership and control. Who owns capital? How is its ownership acquired? Who makes decisions on the allocation of resources between consumption and investment goods? These questions prompted new inquiries into the origins of profits and the determinants of the level and distribution of income and wealth; the role of saving in the intertemporal allocation of resources; and the methodological foundations of alternative interpretations of market economies. To these questions Graziani provided his answers within the theory of the monetary circuit — or the theory of a monetary economy of production, as he also called it after Keynes. He presented this theory in many of his writings and formalised it in a number of models. The best synthesis is Graziani's The Monetary Theory of Production (Graziani 2003), one of the most influential international classics on the circuit approach.

The crucial theoretical focus within the circuit approach is the relationship among money creation, investment and saving. In Graziani's view, banks do not act as mere intermediaries between savers and investors, but rather as the creators of new liquidity. While in the neoclassical formulation (as, for example, in Cannan's 'cloakroom' banking or Hayek's 'brokers' banks'), ${ }^{9}$ bank deposits arise out of consumers' savings, in the circuit approach by contrast "loans make deposits" (Graziani 2003: 82), and "it is technically impossible for the banking system as a whole to collect deposits without having at the same time granted loans of the same amount" (Graziani 2003: 45; see also Graziani 1996a: 140-141). The idea that "in logical terms loans precede deposits" (Graziani 2003: 46) is nowadays accepted by many economists and subscribed to by some of the main Central Banks. For instance, the Bank of England explains that "the majority of money in the modern economy is created by commercial banks making loans", and defines as a "popular misconception" the notion that "banks act simply as intermediaries, lending out deposits that savers place with them" (McLeay et al. 2014: 1).

Once the two ideas that loans make deposits and that bank loans are the main source of money creation entered Graziani's system of thought, all the pieces fitted together, and his theory of the monetary circuit followed as a logical consequence. ${ }^{10}$

\footnotetext{
8 The Arrow-Debreu approach extends general equilibrium theory in this direction by distinguishing goods not merely by their physical characteristics but also by their delivery dates and the state of the world. See e.g. Bliss (1975).

9 Cannan (1921) and von Hayek (1933: 166).

10 With reference to capital formation in the Walrasian model, he wrote (Graziani 1965: 81) "..it is assumed that the agent, even the consumer, directly demands capital goods on the market. This amounts to assuming that every economic agent is simultaneously an entrepreneur and a consumer, an unusual hypothesis, but nevertheless a necessary one in a model such as this, without money and credit. By contrast, if the community were divided into two categories, entrepreneurs on the one side and consumers-workers on the other, and if the former were the only purchasers of capital goods, in the absence of a credit system able to transfer workers' savings to entrepreneurs, any link between consumers' intertemporal
} 
Firstly, modern economies should be characterised as monetary economies, because money is required in all market exchanges and, above all, in the opening stage of the production process, when money wages are advanced to workers.

Secondly, the existence of money is only compatible with a sequential economic process, because money would be useless in a general equilibrium, defined as a situation where all individuals keep their budgets balanced and all transactions are simultaneously carried out after equilibrium prices have been determined (e.g., by a Walrasian auctioneer). In general equilibrium theory, "the whole market mechanism appears to be in the nature of a general barter, made easier by the intermediation of money, possibly obscured by the 'veil' of money, but not altered in its substance" (Graziani 2003: 8).

Thirdly, in genuine monetary economies "money is in the nature of credit" (ibid.: 61).

Fourthly, differential access to bank credit establishes a hierarchy in the economy between those agents who obtain finance for their production plans, and those who do not. This point can be restated in familiar textbook language: in the presence of imperfect capital markets, some agents are subject to liquidity constraints (e.g. they cannot borrow against expected future income). Graziani identifies the latter category with workers, whose purchasing power is thus limited by their income, while entrepreneurs are those select agents that enjoy full access to bank credit (ibid.: 20). This bank-led selection process de facto amounts to establishing a class-based society. True, the relationship between banks and firms is by no means conflict-less: conflicts arise over the interest rate that firms and banks negotiate in the money market. But the deepest or, we may say, the foundational divide is that between the agents who obtain credit and those who, failing to do so, can only earn a living by selling their labour.

Fifthly, the distribution of real income between wages and profits basically depends on entrepreneurs' decisions concerning the level and composition of output, as clarified by the post-Keynesian and Kaleckian theory of distribution, which Graziani accepts and shows to be basically equivalent. He concludes that wage earners as a class do not control their real income: "if unemployed, they have no access to the market, whatever their abilities may be; if employed, they get a monetary income the level of which in real terms escapes any possible previous determination or negotiation", having being predetermined by firms' decisions concerning the production of consumption goods (Graziani 2003: 145).

Finally, the allocation of resources is not determined by consumers' preferences. Once firms have obtained 'finance', they are in a position to decide the composition of output and employment between consumer goods and capital goods irrespective of consumers' intertemporal preferences. This is coherent with Graziani's systematic underplaying of the role of the long-term interest rate established in the financial market relative to the short-term rate determined by firms and entrepreneurs through their negotiations in the money market, which directly affects the initial stage of the

Footnote 10 continued

preferences and the return on investment would disappear. But such a link is a necessary element in any model within the neoclassical approach". If we consider this passage from the point of view of the subsequent development of Graziani's thought, we see that the missing link is his new conception of the banking system. 
monetary circuit. Graziani rightly observed that, from a theoretical point of view, the two interest rates should not be collapsed into one. Starting from this distinction, he developed the more controversial propositions that the long-term interest rate paid on securities is less important than the short-term interest rate and that, under some simplifying hypotheses, it implies no real cost at all for firms (Graziani 2003: 114117).

Underlying his position is the idea that savers do not really become the owners of capital goods by buying the securities sold by firms on capital markets. Ownership and control of capital can only be gained via access to bank credit. This hypothesis is the basic tenet of Graziani's understanding of capitalist systems. As Schumpeter once said, the banker is the 'ephor' of capitalist economies.

\section{The Italian Economy in the International Context}

Graziani's applied work reflected his theoretical evolution from the initial focus on economic dynamics to the analysis of power and conflict in economic relations. But, throughout its evolution, Graziani's empirical work was characterised by a tremendous, successful effort to extract a logic from multifarious facts and to present a reasoned renderings of the succession of economic events.

In Lo sviluppo di un'economia aperta (Graziani 1969) he used his export-led theoretical model described above to explain both the dynamism and the imbalances of the Italian post-war economy. In this dualistic economy, productivity and investment growth are exogenous variables dictated by international competition, while employment is the endogenous variable in the exporting sector. The opposite is the case in the second, residual, sector, which is shielded by international competition and gives employment to the remaining labour force, but achieves low productivity growth. This structural imbalance has a regional impact, because the dynamic sector concentrates in the Northern area of the country and has shallow roots in Southern Italy (the 'Mezzogiorno'). Economic growth and North-South imbalances are thus seen as joint consequences of a single mechanism, namely export-led growth, which also leads to a 'distortion of consumption', i.e. a rise in luxury consumption in the presence of unsatisfied basic needs due to the wage growth that accompanies rising productivity in the dynamic sector.

It is interesting that, differently from some approaches fashionable in more recent times, Graziani's interpretation excluded explanatory variables such as the legacy of (medieval) history, culture, or even the supposedly weak ethical propensities of southern Italians. As a matter of fact, the experience of the 1950s, 1960s and early 1970s was proof that the culture of the entire country changed quickly in response to economic development. Ethical codes respond to incentives.

In spite of the imbalances produced by export-led growth, an optimistic view of the Italian economy's potential development emerges from Graziani (1969) book. It seemed as if those imbalances could be removed within a reasonable time horizon in the context of buoyant economic growth, also with the help of the appropriate development policies that, for a while, governments seemed willing to pursue. But 
these hopes gradually faded from the 1970s onwards, and Graziani documented the grounds for new worries in his subsequent empirical work. ${ }^{11}$

Firstly, the North-South divide, in which Graziani and the Portici group had been investing such great intellectual energy, started to widen again. It should be stressed that the position taken by Graziani, Rossi-Doria and the entire Portici group, and indeed by all the 'Neo-Meridionalisti' (such as, for instance, those working at the SVIMEZ), was one of harsh condemnation of inefficient public expenditures, coupled with a strong defence of industrialization policies aimed at strengthening the Southern productive apparatus (Graziani 1979b:117-120). But these policies were gradually falling out of favour in the Italian economic and political debate and, most importantly, in the governing circles. Graziani's works (together with those of other economists such as Rossi-Doria, Saraceno, etc.) is evidence that the policy of subsidies adopted by the authorities cannot be blamed on the economic strategy advocated by the NeoMeridionalisti, who always rejected such inefficient solutions.

Secondly, and relatedly, the Italian economy as a whole proved unable to reproduce the three ingredients of the 'miracle' years, namely strong investment growth, price stability, and external equilibrium. One of the key factors in the miracle had been the weakness of trade unions, which had given rise to a sustained gap between productivity and wage growth. The miracle came to an end when wages started to rise in 1963, and again in 1969. From that period onwards, Graziani, while always taking account of the entire spectrum of national and international economic and political circumstances, interpreted the evolution of the Italian economy as essentially driven by the conflicts between the main social groups. For example, he saw deflation and unemployment (in 1964-1965), inflation (in 1973-1974) and industrial restructuring (from the end of the 1970s to the 1990s) as alternative measures adopted by industrial capital and economic authorities for the purpose of restraining the strength of workers and their unions (Graziani 1975). The choice between these alternative "workers' discipline devices" (as we may call them) depended upon the accompanying circumstances. For instance, the inflationary strategy was more efficient with flexible exchange rates than it had been in the previous fixed exchange rate regime. However, in the longer run the successful strategy was industrial restructuring: production was decentralised away from large firms and workers were accordingly dispersed among a myriad of small

\footnotetext{
11 In this context, Graziani's best known and most influential book is L'economia Italiana, which went through several editions (Graziani 1972, 1979b, 1989a, b) and developed into Lo Sviluppo dell'Economia Italiana: Dalla Ricostruzione alla Moneta Europea [The Development of the Italian Economy: From Reconstruction to the Euro (Graziani $1998^{2}$ ). Mention should also be made of Crisi e ristrutturazione nell'economia italiana [ Crisis and industrial restructuring in the Italian Economy] (Graziani 1975); Investimenti e disoccupazione nel Mezzogiorno [Investments and Unemployment in Southern Italy], edited jointly with Enrico Pugliese (Graziani and Pugliese 1979); the article "The Mezzogiorno in the Italian Economy" (Graziani 1978a) published in the Cambridge Journal of Economics, and the collection of newspaper articles I conti senza l'oste. Quindici anni di economia Italiana (roughly translated as Don't count your chickens before they hatch. Fifteen years of the Italian economy) (Graziani 1997a). Because of its clarity of exposition, I would also recommend, as an introduction to Graziani's thought, his book Trent'anni di contraddizioni economiche in Italia. Le teorie, la storia, la politica dell'economia [Thirty years of economic contradictions in Italy. Theories, history and the politics of economics] (Graziani 1978b). This is the revised version of a series of lectures he delivered for the " 150 hours" program organised by the FLM (Federation of Metal Workers) for the education of workers.
} 
firms. Consequently, weakened trade unions were less able to promote wage growth and to defend workers' rights (Graziani 1998: 211). This was an original interpretation of industrial decentralisation, and also of the so-called 'industrial districts', which he judged in less favourable terms than other leading Italian economists, although he admitted that, in some specific cases, the industrial district model may have positive implications for social cohesion.

If, as Graziani noted, decentralization was an excellent strategy for governing class conflict, the loss of big firms was not without costs for the Italian economy. Industrial 'dwarfism' is now regarded by many to be a major factor in Italy's economic decline for a variety of reasons, one of them being that small firms are less able to sustain the costs of R\&D expenditures and hence less able to follow the 'high road' to international competitiveness. Along these lines, in his last writings Graziani rang an alarm bell for the Italian economy. Italian firms were now facing increasing competition from both technologically advanced and low-wage countries, just when, with the EMU, they could no longer enjoy the benefits of external devaluations.

The tone of Graziani's final work is one of disenchanted realism: globalization and related factors exerted a downward pressure on real wages at the same time that the European Union was imposing its strict discipline on fiscal policies and aggregate demand. In these circumstances the trend towards greater inequality would gain momentum (Graziani 1998: 253).

Graziani's clear diagnosis and forecast of the Italian malaise is still valid today, and has acquired all the more relevance since the European sovereign debt crisis erupted in 2008 .

\section{History of Economic Thought}

Graziani's theoretical evolution is accompanied by the evolution of his studies and writings on the economists of the past. An exhaustive rendering of his writings on the history of economic thought and analysis is out of the question within the limited space of this article. Therefore, I will merely illustrate some aspects of his methodological approach to this field, and give some examples.

Briefly stated, the history of economic thought was a source of inspiration for Graziani's theoretical constructions. In other words, he used his explorations of other economists' contributions, their conceptions and analytical tools, as well as the theoretical debates in which they had been involved, as devices to clarify theoretical issues. By comparing and juxtaposing alternative approaches and their developments over time, he clarified his own thought, and forged his own arguments and theoretical solutions for the issues involved.

Graziani was interested in the history of the discipline as the history of economic ideas and analysis. However, differently from other exponents of the analytical approach, he did not consider the history of economics to be the history of the gradual discovery of the 'truth'. There is no hint of positivism in his thought. Nobody was a firmer believer in pluralism, and he never talked of 'true' and 'false' doctrines.

Coherently with this approach, Graziani rejected any reconstruction of the discipline's evolution "made in terms of one single chronological process". Rather, he saw 
the history of economics "as being formed by two parallel and conflicting lines of thought": on the one hand, the individualistic approach, and on the other, the view of "the economic process as determined by the actions of conflicting social classes or groups" (Graziani 1992: 221). A paradigmatic case of this approach as a historian are his two volumes Teoria Economica. Prezzi e distribuzione (1979) and Teoria economica. Macroeconomia (1976). Radically revised versions of his textbook Teoria Economica, originally published in 1967, these two books, which reached their fifth edition in 2000, should be considered, when taken together, an outstanding, full-fledged economics treatise. Here, he illustrated the analytical structure of many alternative microand macro-models. Through these investigations, he showed that, according to the individualistic approach, entrepreneurs perform the purely technical task of assembling resources in order to produce goods, in obeisance to the price signals sent by the ultimate 'sovereigns' of economic activity, namely final consumers. By contrast, according to the second approach, macro-groups differ in their power to determine production, employment, and the time profiles of economic variables; the economic process takes the form of a circular process where workers' consumption is merely an intermediary stage in the production process fully controlled by entrepreneurs and firm owners.

Graziani saw much of his own work in the field of the history of economic analysis as "devoted to showing how not only Ricardo and Marx, but also authors like T. R. Malthus, K.Wicksell, J. A. Schumpeter and J. M. Keynes" took the second theoretical approach (Graziani 1992: 221) ${ }^{12}$. He regarded this line of thought as more congenial to his own way of thinking. In this context, he did not read the authors just mentioned with a 'passive' attitude, and did not merely 'absorb' their thought. Quite the contrary: he read them critically, and by so doing he integrated the historical aspect of the discipline into his own theoretical arguments. For instance, in the introductory chapter to his The Monetary Theory of Production (Graziani 2003), he furnished a masterly reconstruction of the development of monetary theory and its 'vicissitudes' from Adam Smith to the present in the light of his own interpretation of the role of money in a monetary economy of production. As another example of his creative use of the history of economic thought, see his reconsideration, and valorisation, of Keynes's articles on the 'finance' motive for demanding money, which had been somewhat underevaluated in previous studies on Keynes's monetary theory Graziani (1984b, 1987, 1988).

In spite of his predominant interest in the above-mentioned authors-from Ricardo to Keynes-he was always careful to render full justice to economists belonging to the alternative stream of thought, and he devoted much effort to showing the logical chains of reasoning that led from their basic assumptions to their results. He did so not merely with reference to general equilibrium theorists, but also to other authors, such as Friedrich von Hayek: see for instance the pains he took to show that Hayek's differences from Keynes concerning the saving-and-investment equilibrium were due

12 On Malthus (and to some extent also on Marx) see Graziani (1980); on Marx, see his contribution dated 1997b; on Wicksell, see, among others, Graziani (1976); on Schumpeter, (Graziani 1977, 1989a). He devoted many studies to the analysis of Keynes's thought, among which Graziani (1981, 1984b, 1987, 1991, 1996a,b). 
to his different basic assumptions (Graziani 1996b). ${ }^{13}$ Moreover, Graziani was also interested in the contradictions in the thought of the authors that accepted some aspects of the traditional approach but, at the same time, introduced substantial features of the monetary circuit approach into their analytical frameworks. See for example his detailed reconstruction of Marco Fanno's theory of money and credit (Graziani and Realfonzo 1992, particularly pp. XLIII-LVIII). Here Fanno is praised for his analysis of the demand for "finance", for the central role that he assigned to the relationship between credit and capital accumulation, and for having "abandoned the idea of metallic money as the only true money"14.

But, of course, Graziani's main concern was to reconstruct the lines of the heterodox, non-neoclassical, approach. He himself said it best in the Presentation of the Series "Economia monetaria": "this line of thought, certainly heterodox and perhaps even heretical (to which Wicksell, Schumpeter, Keynes, Robertson, L. A. Hahn and many others belong) [...] [gives rise to] a different theory of distribution, a different interpretation of the relationships between banks and firms, a different analysis of the accumulation of industrial and financial capital"15.

This sentence clearly illustrates his analytical approach to the history of economics and, at the same time, corroborates the main tenet of the present interpretation of his thought: that capital accumulation was the main focus of Graziani's interest throughout his intellectual life.

\section{Conclusions}

Let me conclude this presentation of Graziani's contributions to economics by again stressing the basic continuity in his thought, and by proposing a final ground for its interpretation.

As we have seen, already in the mid-1960s he was aware of the radical implications of his critique of general equilibrium analysis: as he put it, "the frameworks of general equilibrium theory break up" in a dynamic context. Thus, room was created for an alternative interpretation of how the economic system works; and the monetary theory of production became Graziani's central research interest. The method and frameworks changed, but the central analytical focus was still on capital, which, according to Graziani, is best understood via the study of its monetary circuit.

Many authors laid the foundations of the approach that Graziani felt to be his own analytical 'house'. Among these authors, Wicksell, Marx, Keynes are certainly to be

\footnotetext{
13 I do not share Graziani position on Hayek. I think that in his writings of the 1930s Hayek repeatedly changed his definitions and analysis in order to remedy the logical faults and weaknesses inherent in his treatment of the issue, but he never produced a convincing solution. See Costabile (2005b: 22-27) and, for related reasoning, Costabile (2005a).

14 Among the other Italian monetary economists studied by Graziani, we may recall Gustavo del Vecchio (see Graziani and Realfonzo 1997). However, Del Vecchio was more orthodox than Fanno and, in Graziani's and Realfonzo's opinion, his thought did not go beyond some limited "happy intuitions" in the direction of the circuit approach (ibid.:XXVI).

15 See the back-cover of the books belonging to this series, which Graziani directed for a Neapolitan publishing house.
} 
mentioned as key sources of inspiration for his work. But in my opinion a very special place should be given to Schumpeter, because Schumpeterian themes are to be found in all the stages of Graziani's thought. In the first stage, the central themes were economic dynamics, capital accumulation, and the role of technical progress and innovation in the evolution of economic systems. A related point, common to both authors, was the explicit criticism of "consumer sovereignty". Graziani later focused on the monetary circuit of capital, on the role of banks as creators of money, and on the idea that "the engine of the capitalist process" is the nexus between banks and entrepreneurs, as Graziani said when commenting on Schumpeter's work (Graziani 1977: 28) ${ }^{16}$. The two authors shared this type of analysis too. Finally, Graziani, like Schumpeter, always had an ambivalent attitude towards general equilibrium theory: they both rejected it as useless for the analysis of dynamic processes and of truly monetary economies; but both profoundly understood its logic and analytical constructions, and respected it as an extraordinary intellectual achievement. For all these reasons, Graziani is-I submit—fundamentally a Schumpeterian economist. ${ }^{17}$ And, I would add, he was also similar to Schumpeter in his gentlemanly demeanour and sophistication.

\section{References}

Bellofiore R (2013) A heterodox structural Keynesian: honouring Augusto Graziani. Rev Keynes Econ I $4: 425-430$

Bliss CJ (1975) Capital theory and the distribution of income. North Holland, Amsterdam

Cannan E (1921) The meaning of bank deposits. Economica 1:28-36

Costabile L (1980) Malthus. Sviluppo e ristagno della produzione capitalistica, Einaudi, Torino

Costabile L (1986) Metodo della scienza e teoria economica in Schumpeter. Note su 'L'essenza e i principi dell'economia teorica'. Studi Economici, n.s 29:147-167

Costabile L (2004) Il Centro di Specializzazione e Ricerche Economico-Agrarie e la 'Scuola di Portici'. In: Garofalo G, Graziani A (eds) La formazione degli economisti in Italia (1950-1975), IL Mulino, Bologna, pp 269-309

Costabile L (2005a) Money, cycles and capital formation: von Mises the 'Austrian' vs. Robertson the 'Dynamist'. Cambr J Econ 29(5):685-707

Costabile L (2005b) L'analisi delle fluttuazioni cicliche prima della rivoluzione keynesiana. Studi Economici, LX, n.s, pp 5-61

Costabile L (2014) Augusto Graziani (1933-2014). Hist Econ Thought Policy 1:163-168

Garegnani P (1966) Sulle equazioni walrasiane della capitalizzazione. Una risposta, Giornale degli Economisti e Annali di Economia, n.s 25(3/4):327-335

Graziani (1964) Equilibrio Generale ed Equilibrio Macroeconomico, Giornale degli Economisti e Annali di Economia, n.s 23(9/10):629-644

Graziani A (1965) Equilibrio generale ed equilibrio macroeconomico. ESI, Napoli

Graziani A (1966a) Ancora sulle equazioni walrasiane della capitalizzazione, Giornale degli Economisti e Annali di Economia, n.s 25(9/10):929-932

Graziani A (1966b) Il contenuto della politica economica, unpublished lectures delivered at the SVIMEZ, Rome

Graziani A (1969) Lo sviluppo di un'economia aperta. ESI, Napoli

Graziani A (1972) (ed) L'economia italiana: 1945-1970, Il Mulino, Bologna

\footnotetext{
16 See also Graziani's treatment of Schumpeter's thought in Graziani (1976) and Graziani (1989a).

17 My interpretation is not incompatible with that proposed by Bellofiore (2013), who defines Graziani as a "structuralist Keynesian", a definition in which the adjective refers to the important role given to the "production side" of the economy.
} 
Graziani A (1975) (ed) Introduzione in Id., Crisi e ristrutturazione nell'economia italiana: diciotto interventi, Einaudi, Torino

Graziani A (1976) Teoria economica, 3rd ed. Macroeconomia, ESI, Napoli

Graziani A (1977) "Introduzione" to J.A. Schumpeter, Il processo capitalistico. Cicli economici, Boringhieri, Torino

Graziani A (1978a) The Mezzogiorno in the Italian economy. Cambr J Econ 2(4):355-372

Graziani A (1978b) Trent'anni di contraddizioni economiche in Italia. Le teorie, la storia, la politica dell'economia, Società Editrice Unitaria Sindacale, Roma

Graziani A (1979a) Teoria economica. Prezzi e distribuzione, 3rd ed. ESI, Napoli

Graziani A (1979b) (ed) L'economia italiana dal 1945 a oggi, Il Mulino, Bologna

Graziani A, (1980) Malthus e la teoria della domanda effettiva. Introduction to L. Costabile, (1980) Malthus. Sviluppo e ristagno della produzione capitalistica, Einaudi, Torino

Graziani A (1981) Keynes e il Trattato sulla moneta. In: Graziani A, Imbriani C, Jossa B (eds) Studi di Economia Keynesiana. Liguori, Napoli

Graziani A (1984a) Moneta senza crisi. Studi economici 39(24):3-37

Graziani A (1984b) The debate on Keynes's finance motive. Econ Notes 13:5-33

Graziani A (1987) Keynes' finance motive. Économies et Sociétés 21(9):23-42

Graziani A (1988) Le financement de l'économie dans la pensée de J.M. Keynes Cahiers d'économie politique, $\mathrm{n}^{\circ} 14-15$, La Théorie Générale de John Maynard Keynes : un cinquantenaire: 151-166

Graziani A (1989a) Schumpeter and Italian economic thought in the inter-war period. Studi Economici 37(1):41-83

Graziani A (1989b) The theory of the monetary circuit. Thames Papers in Political Economy, London

Graziani A (1991) La théorie keynésienne de la monnaie et le financement de l'économie. Économie Appliquée 44(1):25-41

Graziani A (1992) Augusto Graziani. In: Arestis P, Sawyer M (eds) A biographical dictionary of dissenting economists. Edward Elgar, Aldershot, UK and Brookfield, USA

Graziani A (1993) Il Mezzogiorno, il mercato, il conflitto, Meridiana, n.16, (January), pp. 201-232, Stable url: http://www.jstor.org/stable/23192719. Accessed 06/02/2014 16:17

Graziani A (1994) La teoria monetaria della produzione. Banca Popolare dell'Etruria e del Lazio - Collana Studi e Ricerche, Arezzo

Graziani A (1996a) Money as purchasing power and money as a stock of wealth in Keynesian economics. In: Delaplace and Nell (eds) Money in motion: the Post-Keynesian and the circulation approaches. Macmillan, London, pp 139-154

Graziani A (1996b) L'equilibrio tra risparmi e investimenti secondo Keynes e Hayek. Rivista Italiana degli Economisti, I 3:325-365

Graziani A (1997a) I conti senza l'oste. Quindici anni di economia Italiana, Bollati Boringhieri, Torino

Graziani A (1997b) The Marxist Theory of Money. Int J Polit Econ 27(2):26-50. Translated by Michael Vale from the original Italian text: A. Graziani, La teoria marxiana della moneta, in C. Mancina, ed. Marx e il mondo contemporaneo, Editori Riuniti, Rome 1986:207-31

Graziani A (1998) Lo sviluppo dell'economia italiana dalla ricostruzione alla moneta europea $\left(2000^{2}\right), 1 \mathrm{st}$ edn. Bollati Boringhieri, Torino

Graziani A (2003) The monetary theory of production. Cambridge University Press, Cambridge

Graziani A (2006) Augusto Graziani. L'economista che ama il dissenso, Intervista a cura di P. Capua, in La Repubblica, Edizione di Napoli, 26 febbraio

Graziani A, Pugliese E (1979) Investimenti e disoccupazione nel Mezzogiorno, Bologna, Il Mulino

Graziani A, Realfonzo R (1992) Introduzione to M.Fanno, Teoria del credito e della circolazione, 1st edn, edited by Riccardo Realfonzo e Augusto Graziani, Napoli, Edizioni Scientifiche Italiane

Graziani A, Realfonzo R (1997) Introduzione to G. Del Vecchio, Lineamenti di Teoria Monetaria, edited by R.Realfonzo, Torino, UTET Libreria Bancaria editrice:XVII-XXVIII

McLeay M, Radia A, Thomas R (2014) Money creation in the modern economy. Bank of England Q Bull 54(1):14-27

Schumpeter JA (1977) Il processo capitalistico. Cicli economici (Italian edition of the adbridged version of Business cycles. A theoretical, historical and statistical analysis). Boringhieri, Torino

von Hayek F (1933) Monetary theory and the trade cycle. Jonathan Cape, London 